\title{
Change in students' upbringing goals in the Czech Republic at the present stage
}

\author{
Oksana I. Dolgaya ${ }^{1, *}$ \\ ${ }^{1}$ ISED RAE, Department of Post-Graduate and Doctoral Studies, 105062, Moscow, Russia
}

\begin{abstract}
The changes of the goals of upbringing in the Czech Republic which took place in the educational sphere at the end of the $20^{\text {th }}$ - early $21^{\text {st }}$ century as a result of considerable reforms are analyzed in the article.
\end{abstract}

At the end of $20^{\text {th }}$ - beginning of $21^{\text {st }}$ century dramatic changes in the economic and social life in the Czech Republic essentially impacted on the theory and practice of Czech education. The conditions of life in the world, filled with information, constantly require individuals' active position and involvement in many of the occurring events and put forward the need for the formation of a new human. In the socialist period of development of the country the upbringing was aimed at the adaptation of young people to existing conditions of social, political and economic life, imposing on it a certain system of values, contributing to the strengthening of ideological ties with the state and the party. Personality was not considered intrinsically valuable, but as a material to be processed in accordance with the requirements of the state, at the same time proclaimed the priority of public interest over personal [1].

In the 70-80s the pedagogical science of Czechoslovakia was actively working on the definition of the objectives of education and upbringing (B. Blizhkovsky, A. Valishova, M. Kralikova, B. Kuyal, V. Parzhizek, Y. Skalkova, etc.). The study of objectives of upbringing and education was aimed at clarifying the concept of "full and harmonious development of personality" which was proclaimed as a main purpose of the school of the socialist period of Czechoslovakia [2]. The understanding of the common goal of scientists and teachers was not identical. Some experts have seen the comprehensiveness from the standpoint of the social role, while others have focused on vocational training [3]. In the Czechoslovakian pedagogical science it had been thought that in upbringing (in the broad sense of the word) the intelligence was slightly overestimated, and, vice versa, the role of emotional development has been underestimated [4].

A significant contribution to the theoretical development of the system of upbringing and education objectives of comprehensively and harmoniously developed personality contributed Kuyal B. [5]. He had supplemented the system of socially significant goals with the personal directed to interests and abilities of students. he called the major subsystems of both groups of objectives as knowledge and skills, the ability, the system of needs and motives, the scientific worldview. Kuyal noted that for successful implementation the system of objectives should be consistent with the structure of the training material, divided into basic, deepen and expanding.
The proclaimed goals were not realized, and separated from the actual results for the reason that adaptive directionality of upbringing and education objectives did not take into account the uniqueness and originality of personality, and many postulates were utopian. The discrepancy of the declared ideals of real public interest led to the ideological disorientation and low efficiency of upbringing [6].

The personality model with a predominant public component, created by the dominant political doctrine was differed by passivity and lack of innovation orientation and conservatism. The model was not in accordance with the new requirements of social development and, as a consequence, could not withstand the competition of the two main social and political systems and two models of personality proposed by these systems in the end of the $20^{\text {th }}$ century [7].

While developing the new strategic directions of the state education policy, objectives and tasks of education the Czech specialists have relied on pan-European and world tendencies and on the documents worked out by the international community. Such documents are: the UNESCO recommendations in which the upbringing of pupils in the spirit of peace, mutual understanding between peoples, respect for the rights and dignity of the personality is considered as the main task of a school [8]; materials of the conference "Environment and Development" organized by UNESCO in 1992 in Rio de Janeiro; the concept of education for the $21^{\text {st }}$ century, elaborated by the international commission of UNESCO under the leadership of $\mathrm{Zh}$. Delora [9].

The pedagogical science of the Czech Republic of the early 90 -ies did not remain aloof from the formation of new tasks and principles of the upbringing of the youth. The problems of upbringing in the new democratic society had been discussing in the pedagogical magazines and newspapers. The titles of the scientific papers appearing at this period indicate the new priorities in this field - great attention was paid to moral upbringing and humanism in education: M. Cipro, "Moral upbringing in the humanistic spirit" [10]; B. Kozhoy, "Humanistic character of intercultural education" [11]; S. Shvets, "Humanization of the general education" [12]; Rosina J., "Problems of objective evaluation of students' moral upbringing " [13]. The article "Reflections on the need to update the principles of education" by Jan Kucera is one of the most important

\footnotetext{
Corresponding author: o-dolgaya@yandex.ru
} 
works devoted to the problems of education in the $90 \mathrm{~s}$ [14].

Kucera suggests: "... to reflect collectively on the cardinal question: what will be the direction of further upbringing; what will be its content; what would be the pedagogical categories; what will be the determining» [14]. Kucera formulated the principles of upbringing in the spirit of the new requirements, emphasizing that they will develop together with the development of society and thus they are open and available for further enrichment [14]:

- pluralism of views and deideologization of upbringing and education;

- democracy and humanism;

- morality and tolerance;

- social consensus in training and upbringing;

- voluntariness and self-dependence in decisionmaking by students;

- purposeful directionality of activities;

- individualization and collectivity in the upbringing and education;

- unity of theory and practice in upbringing, training and practice;

- compliance and gradualness of the requirements;

- illustrativeness and constancy in the upbringing and training;

- optimism and the gladness of the pedagogical process.

The principles have been formulated in a way that in the hidden form they contain other principles that have received a new quality, relevance and effectiveness. For example, the principle of consciousness is a component part of the first three principles simultaneously. The principle of respect for the student's personality refers to the principle of morality and tolerance. The principle of purposefulness and activity of student concerns almost all the above mentioned principles, especially the principle of purposeful activity orientation.

Kucera believes that the basic principle of teaching and upbringing process from the standpoint of preparing young people for life is the principle of pluralism of views and deideologization upbringing and education. The youth have an opportunity to discuss and make their choice, but young people should be prepared to selfunderstanding of various positions and views and to the correct understanding of reality. Therefore, the deideologization of upbringing and education is very important. But this process should not be understood as a separation of upbringing from life. The public conditionality of upbringing is a natural and regular process. In the opinion of Kucera the practical application of this principle means to teach children to respect other people's views.

The notion of pluralism is understood by the author as the existence of many parties and trends, concepts of understanding the world, interests and styles of behavior, values, etc. In the implementation of this principle the teacher plays a special role. The teacher must possess an extensive knowledge and special education in a greater degree than before. The social activity of students plays an important role for forming their own opinions and attitudes. Kucera understands the social activity in a broad sense as a specific form of human activity, aimed at the creation of material and spiritual benefits. He highlights three items of social activity that are important for the realization of the principle of upbringing: the awareness (student consciously chooses, determines and follows his individual and social objectives); the ability to live and work together in a collective; the ability to creation, creativity.

The principle of democracy and humanism logically and in its internal ideas associated with the previous principle. Having in mind the goals of upbringing, the application of this principle means the behavior of the students to an understanding of that democracy, or liberty is not identical with the anarchy that a man can be democratic, humane and free only when he is disciplined, works for the good of society, works specifically on self-education, self-education, selfcontrol.

The principle of morality and tolerance in its inner idea and essence is not new. Its novelty consists in the understanding, transformation, application and needs of the people to assimilate this principle. Tolerance means sufferance, respect for other people's opinions and views. In the practical activity this principle is represented in good relations between students and teachers, between children and parents in the real mutuality of these relations, positive examples of teachers, educators, citizens and their respect for the children and the youth and in taking care of them. Related to this is the respect for voluntary choice of student's activities in their spare time. The self-control of a child can't be started if the child is constantly is being directed. It is important that the teacher must constantly demonstrate tolerance and understanding in working with students. The morality and tolerance constitute an inseparable unity and if less attention is paid to one of the components, the second component necessarily would suffer. The moral personality must be able to act reasonably, not guided by habits, customs, traditions, fashion or public opinion, but he must be able to substantiate his every action and every judgment in a relationship with any person. This principle could include the upbringing of such qualities and values as recognition of other person, self-respect and human dignity, strong friendship, discipline, and others. All this may be inherent to the internally free human being. We also see close connection of the principle of morality and tolerance and the principle of democracy and humanism, they are united by an understanding of human freedom as self-discipline and self-control. Internally a free person is liberated from human spite and envy that makes him happy. According to Kucera, the understanding of this is important for the new direction of upbringing.

The next is the principle of social consensus in upbringing. It is about consent in the society between its members and groups. As the school is a separate world, as a small whole, which consists of upbringing mosaic fragments, it is necessary to create the conditions for consent and harmony, it is essential that the students learning concepts such as humanity, democracy, tolerance could apply them in practical life, and that 
these concepts could contribute to the formation of young people.

In the education process the upbringing communication, exchange of views and information between the participants of upbringing process during learning and in their spare time are the means of reaching a consensus. In the process of such communication the student becomes not only the object but also the subject of upbringing. Thus, the teacher and student work together in the implementation of the objectives of upbringing. Proper communication might become a condition for the occurrence and preservation of a favorable climate as the basic premise of consensus. The ultimate goal of upbringing communication besides of subjectivity of students could become their good breeding and improvement of relations in the school.

The principle of voluntariness and self-dependence in decision-making by the students can be implemented in process of training by interests in their spare time. The pedagogical interference into leisure time of children should be directed to open the scope for internal activity of the students, for their self-development and selfupbringing, to develop their activities on the need for the common benefit, initiative and self-dependence.

The healthy competition is created during the lessons by choice, which allows to bring up the qualities of a strong personality, but simultaneously it is necessary to form morality in children, to form ability to make friends and to help comrades, to develop skills of correct behavior. The lessons in spare time is a very important field of upbringing, where the social self-realization of children based on the principles of voluntary choice and decision-making.

The principle of individualization and collectivism allows teachers to approach to the students, to see their weaknesses, to pay attention to the problems of health, family and social environment, etc. The individualization allows to detect talented children, purposefully develop their individual inclinations and abilities. Simultaneously, this principle assumes creation an atmosphere of healthy competition between students, mutual assistance and good relations, to motivate students to achieve their best results.

The principle of unity of theory and practice of upbringing in pedagogical science is designed for a long time. However, at the present this unity is experiencing a great rise in relation to the advent of new approaches, forms, methods, models in the theory and practice of upbringing.

According to Kucera the conformity and gradualism in requirements are an important principle of upbringing that provides the desire, voluntariness, creative activity during fulfillment of educational and upbringing tasks by the students.

The complex of upbringing principles formulated by Kucera completes the principle of optimism and gladness. It is concerned with mutual trust between the student and pedagogue, with their common gladness of the obtained results. The student and teacher feel the gladness of a well done work in equal measure. The climate that is conducive to progressive creativity and to the participation of students in their own training and upbringing is formed. Comparing the principles proposed by Kucera with the principles on which the Czech education has been based previously, one can say that the first five of them are new for the Czech pedagogy, while others also contain a certain novelty.

The principles of upbringing developed in the 90s by the Czech scientists and pedagogues constitute the basis of many legislative and program documents. In particular, in the School Act of 1990 [15] the upbringing is proclaimed as the objectives and tasks of the Czech School on the basis of scientific knowledge according to the principles of patriotism, humanism and democracy, as well as the intellectual and moral development of a personality, ensuring the aesthetic, healthcare, physical, and ecological upbringing. The principles of humanism and democracy were first mentioned in the School Act, as well as the problems of a healthy lifestyle, human knowledge about himself, his mental and physical health, formation of ecological culture and ecological consciousness of youth. The contemporary Czech government grants its citizens freedom, but at the same time sets high demands and responsibility for their country and for the world development (geopolitical, ecological problems). The European Union membership also requires the tolerance upbringing and respect for other people's traditions, cultural experience, etc. [16]

In the Czech society and in the Government the understanding of the importance of education and upbringing of the younger generation to solve all these problems has been formed. In formulating the new general goals of education and upbringing the Czech pedagogues assume that the contemporary society attaches great importance to the individual abilities and human rights, as well as every single human depends increasingly on other people, on the whole society and on environment.

The more complicated the social life, the more volume of knowledge and skills should assimilate each person to find his place in life. The higher the measure of individual liberty, the higher the requirements to personal maturity, responsibility and creative abilities of every citizen [17].

In accordance with the new conditions of life and new social and personality needs based on the provisions of the White Paper (2001) [18] the general objectives of education (in the broad sense) including the goals of upbringing have been developed and proposed. They are enshrined in the School Act of the Czech Republic $(2005,2012)$ [19]:

- development of a personality in accordance with the age and individual prerequisites and possibilities, preparation for personal and social life, lifelong learning, result of which is work activities and employment; - support for the consciousness of own people belonging to the European and worldwide community, respect for other nations, cultures and values that have emerged during the period of human society development; - cultivation of respect for European cultural traditions and values, for the ethnic, cultural, linguistic and religious affiliation of everyone, regardless of their nationality (the representative of the small or large nation); 
- assimilation of the principles of democracy and the development of a human ability to use his/her basic rights, assimilate values such as liberty, responsibility and tolerance;

- obtaining knowledge from the social and natural sciences, technique, as well as aesthetic, cultural and moral values;

- obtaining knowledge about the environment and its protection.

In the contemporary system of goals and objectives of upbringing and education in the Czech Republic the development of the personality of every individual, his skills and talents needed for successful professional activity throughout life is prioritized. The second group of objectives related to the need for awareness that every individual belongs to the worldwide and European community. After these objectives the acquisition of knowledge from various scientific fields should be followed. Such a hierarchy of objectives of education and upbringing indicates that in contemporary Czech Republic the focus is on upbringing aspects of personality formation, which corresponds to the worldwide trends.

The publication was prepared within the framework of a research project supported by the Russian Foundation for Humanities No. 15-06-10102-a in 2016

\section{References}

1. Reformy obrazovaniya $v$ sovremennom mire: global'nye $i$ regional'nye tendentsii (Izd.ROU, Moscow, 1995)

2. J. Skalkova, Od teorie k praxi vyucovani na stredni vseobecne vzdelavaci skole (Praha, 1978)

3. B. Blizkovsky, Pedagogicka revue, 9, 77-82, 1991)

4. J. Prucha, Perspektivy vzdelani (SPN, Praha, 1983)

5. B. Kujal, $K$ perspektivnimu systemu celozivotni komunisticke vychovy $v$ socialisticke spolecnosti (PU JAK CSAV, Praha, 1977)
6. J. Rosina, Pedagogicka revue 8, 26 (1991)

7. Lidove noviny, 23, 7 (1999)

8. Conseil de l'Europe. Education (CDPS, CP/96/7)

9. Obrazovanie: sokrytoe sokrovishche/Doklad mezhdunarodnoi Komissii po obrazovaniyu XXI veka (UNESCO, 1997)

10. M. Cipro, Pedagogicka revue, 10, 74 (1991)

11. V. Kozon, Pedagogicka revue, 10, 19 (1991)

12. S. Svec, Pedagogicka revue, 6, 342 (1991)

13. J. Rosina, Pedagogicka revue, 8 (1991)

14. J. Kucera, Pedagogicka revue, 10, 97-98 (1991)

15. Skolsky zakon (Praha, 1990) Available online: URL http://www.msmt.cz/dokumenty/novy-skolskyzakon (accessed 08.02.2016)

16. Vyzva pro deset milionu (MSTS, Praha, 2000) Available online: URL http://www.10milionu.cz/cgi-bin/toISO-88591/studie/1 studie.html (accessed 08.02.2016)

17. Koncepce statni politiky ve vztahu $k$ mlade generaci v Ceske Republice do roku 2002 (MSMT, 1995) Available online: URL http://www.msmt.cz/cp1250/supina5/Statpol.htm (accessed 08.02.2016)

18. Bila kniha (Narodni program rozvoje vzdelavani $v$ Ceske Republice (Praha, 2001) Available online: URL www.msmt.cz (accessed 08.02.2016)

19. Skolsky zakon (Praha, 2004, 2012) Available online: URL http://www.msmt.cz/dokumenty/novyskolsky-zakon (accessed 08.02.2016) 